\title{
Marriage under the age of legal perspective on Sasak tribe in Indonesia
}

\author{
Ihsan Ihsan * \\ Sekolah Tinggi Keguruan dan Ilmu Pendidikan (STKIP) Muhammadiyah Sorong. \\ Jl. K.H. Ahmad Dahlan No. 1, Malawele, Sorong, Papua Barat 98418, Indonesia. \\ ihsanahmad@stkipmuhsorong.ac.id \\ * Corresponding Author
}

\section{ARTICLE INFO}

\section{Article History}

Received:

7 January 2020;

Revised:

29 March 2020;

Accepted:

30 March 2020

\section{Keywords}

Merariq Kodeq;

Sasak society;

Culture;

Local tradition

\begin{abstract}
The existing tradition of marriage under age (Merariq Kodeq), this research aims to understand the consciousness of the national law, which prevails in the middle of the community with the existence of the marriage laws related to the age of marriage. This study used a qualitative approach to know the factors causing, the form of offense, impact, and effort of government in marriage underage in the Parampuan village Lombok Barat regency. The study results are as follows. Factors affect the Merariq Kodeq among the others because of the low financial of a family, factors of low public education, personal factors influenced by environment intercommunication, factors parental concern to the intercommunication of his son, cultural factors that still adopted the community. Abuses that are not in accordance with the provisions of the constitution based on Indonesian law system marriage, which the age of children in doing marriage, the validity of marriage did not participate noted in the office of religious affairs the rights of the child and teenage as the young generation. The impact of that occurs as a result of Merariq Kodeq is premature pregnancy, dropping out of school, domestic violence, divorce, psychological trauma as well as vulnerable to marriage in below the hands. The government commitment to socializing in the village, guidance, the documentary movie about the dangers of marriage on the below age, and the information center for counseling sex education for teenagers.
\end{abstract}

This is an open access article under the $\mathrm{CC}-\mathrm{BY}-\mathrm{SA}$ license.

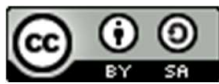

\section{INTRODUCTION}

Every creature is created by in pairs. So too are people, if other creatures in pairs do not need certain ordinances and regulations, then it is with humans. In humans there are several provisions that are the rules of choosing a partner and to live with a partner. Both the rules of religion, customs, traditions, and social society (Zulhadi \& Mohsi, 2019, p. 79). Marriage is a bond that is celebrated or implemented by two people to formalize the marriage ties following religious norms, legal norms, and social norms. Marriage has a variety and variations according to ethnic traditions, religion, culture, and social class. The use of certain customs or rules is sometimes related to specific religious rules or laws. Legalized ratification of marriage usually occurs when a written document that records the marriage is signed. The wedding ceremony itself is usually an event that is held to carry out the ceremony based on applicable customs, and the opportunity to celebrate it with friends and family. Men and women who are having a wedding are called brides, and after the ceremony is over, they are called husband and wife in marriage ties.

According to the Law, a marriage carried out to obtain positive values. It can be it happiness, a happy family, love, and affection, so that there are no things that result in a loss between one partner 
both inwardly and outwardly. In addition, marriage legally affects the rights and obligations, also administratively gives the duty and authority to the state to enter one's arena or personal territory, such as determining the legality, legal status of each party, including legal relations with third parties, for example between sons-in-law with in-laws (Rato, 2011, p. 29). The government strives so neatly and even regulates marital life as a legal act that is giving birth to the rights and obligations of each party, including the rights and obligations of both the husband and the woman and vice versa. The government also stipulates several other rules that to bring about marriage in accordance with article 1 of Law Number 1 of 1974, including providing limits on the age of marriage so that mental and physical maturity can later have implications for household harmony. This is an attempt by the state to protect marriages that can damage families. The conditions that exist in people's lives, the rules face serious obstacles related to the supporting rules, social conditions, the low education, economy, and culture of the community, as well as religious understanding. The existence of a minimum age limit for the bride and groom to register a marriage, but not accompanied by easy access and sanctions for violators, ultimately has a negative impact on society.

The practice of early marriage was often influenced by local traditions (Salmah, 2016, p. 37). Underage marriage as a form of behavior can be said to have been entrenched in Lombok society. It means that an individual's boundary by reviewing the readiness and maturity of an individual's age does not become a barrier for someone to keep getting married (Landung, Thaha, \& Abdullah, 2009, p. 90). These young marriages invite many problems, because marriages are at high risk, especially when followed by pregnancy. Socially, girls who marry at a young age tend to experience many difficulties, especially if they are divorced by their husbands (Gultom, 2013, p. 47). As a result, many daughters who have been returned by their husbands tend to be brave enough to go to big cities to get better job opportunities and to survive. It is important for adolescents as children who are in the transition from childhood to adulthood during this transition period usually occurs accelerated growth in terms of physical and psychological. Both in terms of body shape, attitudes, ways of thinking, and acting, they are no longer children. They also have not been said to be mature humans who have the maturity of mind.

Circumstances in the middle of the community, on the one hand, there are customary laws that apply in a community group that regulates and resolves various kinds of problems that occur, this can not be denied to be eliminated in the community, customary law is a cultural product, customary law contains about cultural values as human creativity, initiative, and taste (Rato, 2011, p. 8). Means customary law born values and culture that are upheld and respected in a society that cannot be contested by anyone. So the customary law does grow and develop from the community as stated by Friedman (1967, p. 211) that living law is also part of the legal system that applies to a country whose existence is recognized. One of the concerns is that the Merarik Kodeq tradition is unique and, at the same time, attracts attention. It because, in addition to paying attention to gaps with Islamic values, also in practice, it is not uncommon to give birth to complex social problems, both during flight and in the process of resolution (Kaharuddin Sulkhad, 2013, p. 7).

Sasak people live on Lombok Island which belongs to East Nusa Tenggara province. Lombok Island has a culture. Culture is a way of life that develops and is shared by a group of people and passed down from generation to generation. Culture is formed from many complex elements, including religious and political systems, customs, language, tools, clothing, buildings, and artwork (Solikatun, Karyadi, \& Wijayanti, 2018, p. 2). The culture is influenced by the private Sasak people Tindih, Maliq, and Merang (Marijo, 2019, p. 35). One of the cultures that is in Lombok is Merariq Codeq. Sasak people call marriage underage as Merariq Kodeq. Customary law in the Sasak community legalizes this so that there is a mention that distinguishes it from Merariq. It is common in carrying ordinary elopement girls by running away underage girls called Merariq Kodeq. Merariq Codeq can be said as Habitus. According to the Womb $(2019$, p. 30) Habitus is a reproduced habit and becomes a general view in society as a standard provision. Sasak people adhere to the culture that has existed for a long time. According to Murahim (2011, p. 69). The compliance with respect to and role in the community is deeply noticed by the Sasak people.

Seeing the phenomenon that occurs in marriages, on the one hand, the government regulates through Law Number 1 of 1974 concerning marriage that provides age limits for marriages in order that the marriages can be harmonious and not cause much conflict. The provision of dispensations 
has also stated in legislation, on the other hand customary law gives flexibility in marriage regardless of age. The existence of socio-legal problems in the community there makes its interest in finding meaning from phenomenology. So the purpose of this research is based on knowing national legal awareness that applies in society with the existence of the marriage law related to marital age. It hopes that all social aspects of society and national legal awareness can clearly describe.

\section{METHOD}

Based on the problems raised in this study, which emphasize the case of underage marriages, this study uses a qualitative approach, which is a research approach that is intended to produce data in the form of written or oral words from the people observed. This research produces descriptive data, systematic, factual, and accurate depiction of observed phenomena, especially primarily marriages which are intended in this study are a form of bonding or marriage that one or both partners under the age of 20 years or are still teenagers. The problems examined in this study include the causes, forms of violations, impacts, and efforts of the government involved in underage marriages. This research conduct in the Parampuan village, West Lombok. Research time, December 2015 to April 2016.

The sampling technique used is purposive sampling. Data sources used included informants consisting of the Office of Religious Affairs (Kantor Urusan Agama Repubik Indonesia), Head of Legal Affairs of the Religious Courts (PA), perpetrators of underage marriages (6 people), Community Leaders, Customary Leaders, Central Statistics Agency (BPS) staff. Besides archives or official documents that codified with underage marriages. From the results of a search for documents related to underage marriages obtained from the Parampuan village, West Nusa Tenggara, religious affairs office Labuapi village, Badan Pusat Statistik (BPS), and the West Lombok Religious Court. Data collection techniques, sources of evidence that can be the focus of case study data collection through in-depth interviews, observation, and documentation review (Yin, 2015, p. 103). Interviews conduct to explore information about factors that cause underage marriages, marital violations related to marital law and child rights, their impact on children and families, and government efforts to prevent underage marriages. That while observations made to see firsthand the activities related to community activities, especially life activities in the families of new-age couples. The documentary intent to obtain and study documented data, such as activity reports, decision letters, legislation, books regarding the culture of the Sasak people. Data validity test through 4 types of triangulation as an inspection technique to achieve validity, namely source triangulation, method triangulation, theory triangulation, and research triangulation.

From the results of the data collection will be analyzed descriptively with a qualitative data approach (Creswell, 2014, pp. 276-277). The data analysis phase includes: processing and preparing data for analysis, the general sense of the information obtained and reflecting its overall meaning, analyzing more details by coding data, coding process to describe settings, people, categories, and themes-themes to be analyzed. These descriptions and themes will restate in qualitative narratives or reports. The final step in data analysis is to interpret or interpret the data.

\section{FINDINGS AND DISCCUSIONS}

Communities in the village of Parampuan still maintain the customs and culture that apply in each region. That has become a culture that is the identity of the community when they want to get married. Besides that, the thanksgiving culture before harvest is still so thick. There are still many other customs that still exist in the middle of that society. In the village community, the ability to meet the necessities of life, they earn a living by selling around to become street vendors and even become farm laborers. That namely farming in other people's fields and becoming farmers because the condition of the village fills with people's homes compared to a small stretch of rice fields. This condition then causes children to drop out of school economic conditions that cannot support their needs. The level of education at a young age becomes very important to produce a generation that can produce work and creativity on the Lombok Island, especially Sasak women who do not receive much higher education. Sasak women prefer to marry at a young age, especially the economic factors 
which make it impossible to continue higher education. So, when children are grown-up and able to earn their living have been married at a young age will occur so that schools become unable to continue. That the impact is there are dropouts in junior high school bench, high school, and even elementary school. Merariq Kodeq cannot be limited.

Factors that influence the phenomenon of early marriage

Conditions in the life of the community are often found marriages of minors (women under the age of 16 years) due to various factors. It does not only violate the law but poses a significant risk to the adolescent's reproductive health. However, there are still many parties who do not understand and are aware of the problem of early marriage. It mainly in rural, remote, and border areas, so that early marriages with a variety of reasons still occur. Factors underlying the occurrence of underage marriages in society is economic, education, social, and habits.

\section{Economic Factors}

A weak economy encourages parents to get their children married soon, so the responsibility of parents to meet the economic needs of their children will be reduced. Because married children are the responsibility of their husbands. The economy is material that use for daily life or the future. The majority of the village of Parsibility who make a living as farmers, or farm laborers, make their welfare levels tend to be low, their income is very limited so that they are unable to provide and meet adequate living facilities for daily life, in line with his opinion Lorenz, Conger, Simon, Whitbeck, and Elder (1999, p. 353) which states that children generally experience such adversity through its effects on family relationships. Children's dependence on the family tends to place them at particular risk from economic hardship, to family economic hardship and its effects on family processes. The people of Parampu Village assume that by marrying their children, their burden reduces, because their married children will have their own lives, including meeting the economic needs of their families.

\section{Education Factors}

The educational setting determines the level of community understanding of the contents and objectives of Law No.1 of 1974 concerning marriage and Law No. 32 of 2014 concerning child protection. Someone who has a relatively high educational background tends to have a thorough understanding of legal provisions. The perpetrators of underage marriages vary in their education, ranging from elementary, junior high, and high school, although not graduated. According to Pratiwi, Angraini, Padila, Nopiawati, and Yandrizal (2019, p. 23) children's age marriage occurs due to education, economic factors, unwilling to be the burden of parents, lack of knowledge about the effects of married in children's age, and the absence of other activities after school dropouts. According to Muntamah, Latifiani, and Arifin (2019, p. 2), low community education is one factor in the occurrence of underage marriages in the village of Portability. Based on the formulation of Law number 20 of 2003 concerning the National education system, education is defined as a conscious and planned effort to create an atmosphere of learning and learning process so that students actively develop their potential to have spiritual strength, self-control, personality, intelligence, noble character, and the skills needed by themselves, society, nation, and country. Low education affects the mindset of parents and children in the village of Parampu, and their thinking horizons become narrow, they tend to surrender to the situation. Low education also has implications for the community's understanding of the applicable provisions or existing marriage laws. Children quickly follow the wishes of parents without consideration for their future; it all depends on parents or resigned to the situation.

\section{Social Factors}

Association makes underage marriage a factor. Today's associations carried out by people are caused by sophisticated technology and advanced thinking. So that they are free to think about themselves so that associations that are as free as possible are consistent with the opinions of Calhim, Immler, \& Birkhead (2007, p. 13) who argue that promiscuity the fact that, in many cases, lazy achieve high reproductive success by copulating with several different females. At the same time, as 
accepted male promises as to the norm and as an import critical of sexual selection, females as sexually monogamous and faithful to a partner for at least a single breeding attempt. By doing so, he automatically assumed that sexual selection cease once an individual of either sex had acquired a mating partner. Adolescent sexual drive is high because of the influence of the social environment of teenagers who start permissive (like to allow/allow) and almost without limits. In the end, physically, children can look more mature and mature faster, but psychologically, economically, religiously, socially. Even the right to live correctly and prosperously, they set aside because other forms of independence may not be able to build a new community called family. Child marriages, or often also called early marriages, are traditional practices that have long been known and widespread throughout the world. The study of the library records two children's marriage patterns, which is to marry a daughter with adult males and to reconcil the child with the woman who is done by the parents of both children (Djamilah \& Kartikawati, 2014, p. 3)

\section{The Habits}

The habits of society directly influence the formation of one's thinking paradigm, which reflects in their attitudes and behavior. In this case, the decision of some people to get married at a young age or underage marriage is related to children's rights that are not following national law. It is not according to law No. 1 of 1974 concerning marriage and Law No. 32 of 2014 concerning child protection is influenced by the habits that have always been carried out by its predecessors. Society consists of a group of people who occupy a specific area. Showing integrity, based on shared experience in the form of culture, has an awareness of the unity of residence, and, if necessary, can act together. In a society, there is a habit that base on a collective action that we know as a tradition. The habits of the community are motivated by the assessment of community members to those who are not married at the age of 20 years as an old virgin for girls and old boys for boys. The legal awareness of the village community of Parsibility influence by environmental factors, customs and habits, education factors, and economic background. Marriage happens to children is an essential cause of problems where children who are married. It especially women who then have to leave school to marginalize in life from the economic, social, and cultural aspects. Have also shown that the limited educational opportunities for children become violations of human rights.

\section{Violations of The Merariq Kodeq in Terms of The Marriage Law}

Marriage can be carried out a marriage according to the provisions of the existing Act, among others must meet one of the formal requirements/objective requirements, which are internal in Law Number 1 of 1974, concerning age restrictions/minimum age to get married, namely for men are 19 years old. Women have reached the age of 16 years (the provisions of article 7 paragraph (1) of Law Number 1 of 1974). Provisions with a minimum age limit intend so that the two parties are truly prepared and mature both in terms of physical, psychological, and mental. Besides, this age restriction is to maintain the health of husband and wife and descendants (Abdulkadir, 2000, p. 77).

Thus marriages under the age of 19 years for men and 16 years for women who are still categorized as "children" according to the provisions of the Marriage Law means that they do not meet the specified requirements and violations have occurred. Data from the results of research that shows the level of Merariq Kodeq, which in 2013 and 2014 was quite high compared to 2015, has decreased. The result of the government is hard work that can provide socialization to the community and Non-Governmental Organizations (NGOs). That helped to save the younger generation from staying in school and receiving the highest education in order to be able to produce a smart generation. It can be seen in Figure 1, which shows the level of Merariq Kodeq in the Sasak community, especially in the Perampuanan village.

There is a social and cultural view in NTB that women who have experienced puberty at the age of 12-15 years can get married. Besides, the Lombok Sasak tribe in NTB itself has an elopement culture known as "Merariq." A tradition practiced man who wants to marry the woman he chooses by running away from the girl without the consent of the woman and his woman's family. Underage marriages can cause legal problems. Underage marriages are addressed differently by customary law, Islamic law, and national law. This fact gave birth to two legal issues. They were related to the 
harmonization of laws between one legal system with another legal system and marriage law legislation in Indonesia related to underage marriages. Protected children aim to ensure the fulfillment of children's rights so that they can live, grow, develop, and participate optimally in accordance with human dignity and dignity, and get protection from violence and discrimination, for the realization of quality, noble, and prosperous Indonesian children.

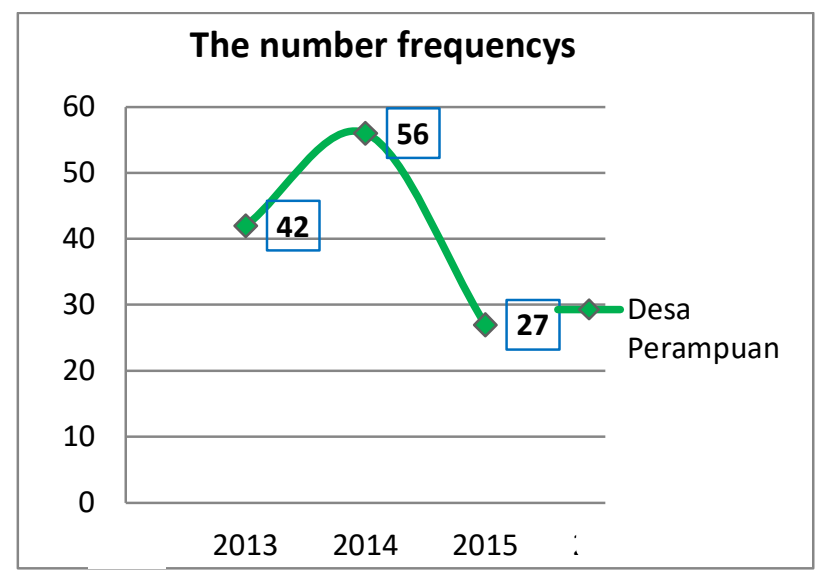

Figure 1. Graph of Marriage Rate for Young Age Women $<16$ Years Labuapi Subdistrict, Perampu village

(Source: Office of Religious Affairs (KUA) of Labuapi District and Badan Kependudukan dan Keluarga Berencana Nasional (BKKBN) in 2015)

The occurrence of underage marriages that occur are not recorded marriages, with marriages not recorded not without risk that the main disadvantage is the wife and children born. Because, if he does not have his marriage documents, such as a marriage certificate, then he will have difficulty claiming his rights as a wife related to divorce, inheritance, family benefits, and others. Marriage is a civil matter-citizens' personal affairs. It makes many people question why the state must regulate marital matters is not marriage in the private sphere. Marriage matters are indeed in the area of civil. However, these events are legal events that cause and effect and the obligations of the parties. So, regulation from the state is still necessary. Law No. 1 of 1974 has tried to regulate by unifying marriage law. Religious law and customary law accommodate in the Act, in addition to Western civil law. Moreover, this is not an easy matter, because forever unification in the area of personal law and family law is something difficult. Indonesia is a country rich in legal plurality and social-cultural plurality.

If the state does not regulate marriages, there will be the potential for injustice to be born for certain parties, especially for women and children born. Furthermore, finally, it will spread to the extended family, the environment, the community, until finally, it becomes a problem for the country as well. Law on the Elimination of Domestic Violence No. 23 of 2004 was born partly because of the rampant phenomenon of marriage violence. Marriage at a young age either because of compulsion or not usually cause an unfavorable response from some people who tend to assume that marriage occurs due to bad relationships. Young marriages also usually do not last long and end in divorce or, for example, a spouse dies, many young widows will emerge. The widow, who is still a child, will have difficulty in fulfilling the needs of herself and her children because of the many limitations they have. The impacts that occur when underage elopement (Merariq Kodeq) occurs in the Sasak community.

\section{Premature Pregnancy}

Pregnancy at a young age can have dangerous consequences. That means, both for young mothers and their babies, young mothers are at risk of giving birth to premature babies with belowaverage body weight. Babies born weighing less than usual have a risk of death 20 times greater in 
their first year than healthy babies (Badan Kependudukan dan Keluarga Berencana Nasional, 2015, p. 3).

\section{Domestic Violence}

It is undeniable that as a result of domestic violence will shake emotionally and psychologically. Which directly or indirectly will affect his life; violence often occurs against vulnerable children and women. The so-called vulnerable is because of the disadvantaged position of children and women, children and women have a high risk of experiencing disorders and problems in their development (Gultom, 2013, p. 15). Research data shows that three victims of domestic violence did not report to the authorities due to their lack of knowledge about the reporting process. The costs that had to provide apart from that they considered family integrity. Child factor, whereas besides that, there was a legal aid agency that provided his services to socialize to every village on the island of Lombok. According to Khaerani $(2019$, p. 1) Domestic violence is caused by family problems. The problems in many families are initiated by the lack of a person when marriage, whether physical or psychic maturity. The physical and psychic maturity is measured from one's age.

\section{Uneducated and Dropouts}

The elopement of school-age children, indirectly the Sasak custom provides legality for the occurrence of the marriage. That often, the customary stakeholders indirectly formalize the marriage, even though the woman will be the second or third wife of the man who escaped. So that often village leaders, customs, and religion become the main actors who legalize these conditions.

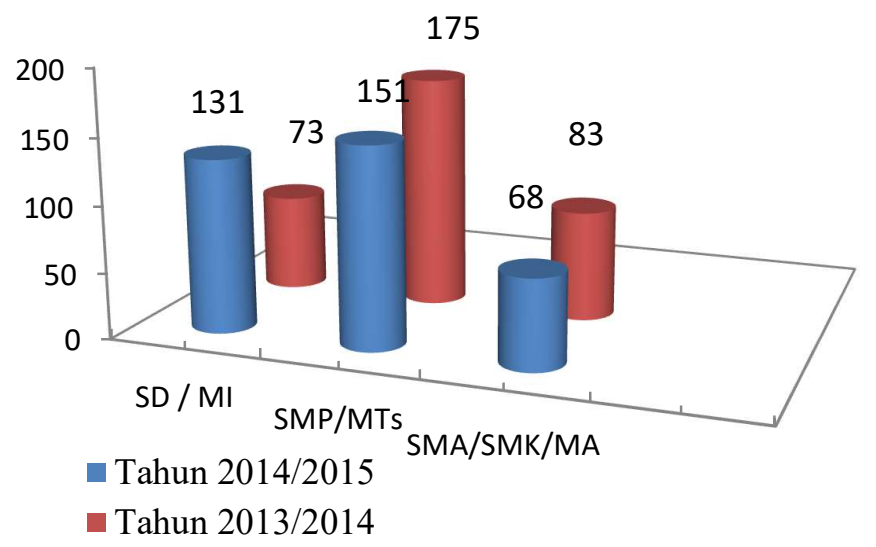

Figure 2. School Dropouts Rate (APS) in West Lombok Regency in 2013-2015

(Source: West Lombok Statistics Center, 2015)

\section{Divorce}

Due to the disharmony of the household, as well as communication that is not in line with marital household conditions at a young age, can have an impact on divorce. It is ultimately inevitable, and the victims are women who cannot continue school or even ashamed to continue their studies. So widowed status at a young age becomes a separate identity. Finally, to continue their lives, they prefer to migrate abroad. It is the impact that occurs due to divorce in customary law. However, divorce is permissible but needs to be avoided according to customary law, because divorce can break the marital relationship that should be maintained by husband and wife. termination of marital relations due to divorce in customary law is not only understood as a form of termination of physical and mental relationships with associations in families and communities in which husbands and wives become members of their families and members of their communities (Syaifuddin, Turatmiyah, \& Yahanan, 2013, p. 26)

In line with his opinion Goode (1985) that early marriage does not infrequently bring up many very complicated problems in the household, and often end in divorce (Goode. 1985, p. 194). 
It is important to consider by Sasak women that after divorce the effort to provide for themselves becomes a moral and inner burden that must be faced because of this condition many migrate abroad to make a living.

\section{Psychological Trauma}

The situation of the death rate of young mothers, domestic violence, this situation can have a traumatic impact on the young mother, thereby depriving her of her childhood, before she learns about life and reacts appropriately to herself, she must nurture and raise the baby In short, it is rushed to become an unnatural and instant adult. Anger and rejection are attitudes that are common and usually last for an extended period of time, and this is what gives rise to prolonged psychological trauma. However, without us realizing there are many other effects of underage marriages. There are impacts on health, those that have an impact on the psychic and family life of adolescents, especially women, among others related to children's rights, there are three major problems faced by married children at a young age, regarding the loss of childhood and adolescence, the loss of personnel freedom and the lack of opportunities to develop fully in addition to the denial of psychosocial and emotional well-being, reproductive health and opportunities to pursue higher levels of formal education.

Early marriage also has implications for the welfare of the family and in society as a whole. For women who are not interested and are not ready to carry out their role as mothers who can contribute to society, there are costs that must be paid at every level, starting from the individual, family level, to the nation as a whole. Of the various impacts that occur, it is natural for the law on marriage to review in its application to the community, legal review. According to Rousco Pound Law is not a static state. However, a process, its formation, and its interpretation and application should link to social facts (Ali, 2006, p. 34). Emphasis on the practical activities of law in society. Therefore, he distinguishes law in the book on one hand and law in action on the other hand.

Every legal rule applies in Indonesia in order to analyze the condition of the community, whether it is suitable and willing to accept the laws made. There is no overlap in their application between positive law and customary law so that it will give birth to a balance of life. Caring about the rights of children to all parties that children who are married, are legally considered as adults even though they are under 18 years of age then lose all protection that is their right based on children's rights. In this case, the child will also lose his rights, which are also guaranteed based on the Indonesian Constitution and Law No. 23 of 2002 concerning child protection. Then reminds further that based on the rights of the child, the State must take steps both in the field of legislation and administratively to realize children's rights. Context of the right to health and growth and development, the state obliged to ensure that all legal provisions guarantee these rights, including, in this case, determining the minimum age of marriage.

Childhood is a time of play, creativity, learning, exploring in order to grow according to his age. The provisions of article 20 of Law number 23 of 2002 stipulate that the state, government, teachers, the community and parents are obliged and responsible for the implementation of child protection. The obligations and responsibilities of family and parents in child protection efforts regulate in the provisions of article 26 of Law number 23 of 2002, consist of: 1.) Caring for, caring for, educating and protecting children; 2.) Growing and developing children according to their abilities, talents, and interests; and 3.) Prevents marriages at the age of children. Based on the above provisions, it has explicitly stated that parents must prevent marriages at the age of children. Children need protection because children cannot protect their rights themselves. Therefore the State, the community, has an interest in seeking to protect the rights of children (Gultom, 2013, p. 39). If parents are absent or are not known to exist, or for some reason, their obligations and responsibilities cannot carry out. Then the obligations and responsibilities of the family, which are carried out in accordance with the provisions of the applicable laws and regulations.

The formation of public legal awareness of underage marriages influences by factors of knowledge, understanding of the contents of the regulations, attitudes, and behaviors that are display as appreciation and public observance of the rules. It was the same with Soekanto (1983, p. 122) which states that: The issue of public legal awareness, actually concerns the factors whether a particular legal provision is known, understood, obeyed and respected. If the community members 
only know a legal provision, then the level of legal awareness is still lower than if they understand it. Building legal awareness is not easy; not everyone has that awareness. Law as a social phenomenon is an institution and community control. Within the community, various institutions are found, each of which is needed in the community to meet their needs and facilitate the fulfillment of those needs, because of their function, the community needs the presence of an institution as an understanding of legal awareness.

The importance of building awareness that is aware of the law expects to support and make the community uphold the institution/rule as the fulfillment of the need to crave legal obedience and order. The role of law in society as the goal of the law itself is to ensure certainty and well-being, the fulfillment of rights, justice, in people's lives there is always a difference between the patterns of behavior or behavior that apply in society with the patterns of behavior desired by the norm legal norms. It can lead to a problem in the form of social inequality so that at certain times there tends to be conflict and social tensions. That can undoubtedly disrupt the course of changes in society in the desired direction. Such a situation occurs because the existence of created law expected to use as a standard (standard) in acting for the community without legal awareness, so there tends to be no legal observance.

\section{Government Efforts to Prevent Underage Marriages}

Underage marriage is a social phenomenon that often occurs in Indonesia in particular. So there is no reason for certain parties to legalize their actions related to the marriage of minors. The efforts made by the government are: 1.) Commitment; 2.) Socialization; and 3.) Guidance.

\section{Commitment}

The government's effort is seriously committed to enforcing the applicable law regarding the marriage of minors so that those who want to marry a minor think twice before doing so.

\section{Socialization}

The government must be more active in socializing the laws relating to the marriage of minors along with sanctions when violating them and explaining the worst risks that can occur as a result of underage marriage to the public. It hopes that with these efforts, the public knows and is aware that marriage Minors are wrong and should avoid.

\section{Guidance}

Guidance to adolescents and clarity about sex education or education on reproductive health (reproductive health) or the term cool sex education should be given to children who have grown up or teenagers, both through formal and informal education. This is important to prevent sexual education bias and knowledge about reproductive health among adolescents. From this description, it is clear that the government prohibits early marriage, which expressly states in the Child Protection Act. However, such matter is not explicitly stated and is supported in the Marriage Law because the Marriage Law only provides a reasonable age limit to be able to carry out marriage and not considering that the age limit in the provision includes in the category of what is said to be a "child" who must get legal protection. This is also stated in the human rights act. Likewise, in the religious aspect, there is also no age restriction for a marriage because it is very individual and relative, so where the measure of benefit returns to each individual.

Conversely, in the case of postponing marriage to mature age also contains positive values, it can use as the primary choice. Thus, when viewed from government policy and religious law, both contain elements of prosperity. It is just that the element of legal protection against age that categorizes as a child has not explicitly regulated. Huge and meaningful capital to achieve happiness. When classified aspects that must be owned by someone as a measure of personal quality, causing marital age restrictions can not avoid. At least there are several types of things expected from maturity, such as: 1.) Education and skills, In the field of education and skills is a crucial aspect as a provision of abilities that must possess for someone who holds a marriage. It is as a support and source of earning a living to meet all needs in the household. In the educational process that pursued, 
it hopes that someone can see science as an essential provision when compared to other potentials; 2.) Psychologican and biological, the solid mentality is a significant force in obtaining the integrity of a household. Physical and psychological balance that exists in each human can produce endurance and clarity of mind in solving various types of problems encountered. New potential minds can emerge after experiencing various processes and developments. The biological aspect is a potential that is very dominant towards household harmony. Therefore, its existence should not ignore; and 3.) Social-cultural, on this site, an individual expects to be able to read the conditions in the surrounding environment and be able to adjust them. It is to create an atmosphere in which the surrounding community recognizes a fostered household as part of community members, so that the families formed do not feel isolated from public relations

\section{CONCLUSION}

. Underage marriages among adolescents cause by various factors, including factors of family economic limitations, low community education factors affecting the narrow mindset, personal factors that are influenced by the social environment and changing the mindset of children and adolescents, family worry factors about the association of children, cultural factors that are still shared by some people, and also the disharmony of the laws that exist in Indonesia. Early age marriages cause violations that are not in accordance with the provisions of the marriage law, namely the age of children in conducting marriages, the validity of marriages is only carried out in accordance with customary law and Islamic law but does not participate in disability in the Office of Religious Affairs. Underage marriages affect the lives of children and adolescents as the nation's next generation. These impacts have an impact on the quality of the family produced, in terms of physical unpreparedness for teenage mothers to conceive and give birth to their babies, as well as psychological readiness in dealing with social or economic problems in the household, and fostering marriage and being responsible parents answer.

Efforts made by the government to prevent underage marriages include commitment, outreach, training, documentary filmmaking due to underage marriages, and counseling about the importance of not marrying at an early age, the government must think of the best things regarding the lives of children. The best interests of the child must be seen from the child's point of view, not from an adult's perspective. Protecting children and young people from the exploitation of marriage can be the basis for a better life. Their way of thinking and behavior because what makes a marriage good or bad is the perpetrator of the marriage itself.

\section{REFERENCES}

Abdulkadir, M. (2000). Hukum perdata Indonesia. Bandung: Citra Aditya Bakti.

Ali, Z. (2006). Hukum perdata Islam. Jakarta: Sinar Grafika.

Badan Kependudukan dan Keluarga Berencana Nasional Provinsi Jawa Timur. (2015). Tingkat perkawinan usia muda perempuan $<16$ tahun Kecamatan Labuapi desa Perampuan, Lombok Barat.

Calhim, S., Immler, S., \&. Birkhead, T. R. (2007). Postcopulatory sexual selection is associated with reduced variation in sperm morphology. PloS One, 2(5): e413, 1-6. Doi: http://dx.doi.org/10.1371/journal.pone.0000413

Creswell, J. W. (2013). Research design: Pendekatan kualitatif, kuantitatif, dan mixed. Yogyakarta: Pustaka Pelajar.

Djamilah, D., \& Kartikawati, R. (2014). Dampak perkawinan anak di Indonesia. Jurnal Studi Pemuda, 3(1), 1-16. Doi: https://doi.org/10.22146/studipemudaugm.32033

Friedman, L. M. (1967). Legal theory. New York: Columbia University.

Goode, W. J. (1985). Sosiologi keluarga (Laila Hanoum Hasyim, Trans). Jakarta: Bia Aksara. 
Gultom, M. (2013). Perlindungan hukum terhadap anak dan perempuan. Bandung: Refika Aditama.

Khaerani, S. N. (2019). Faktor ekonomi dalam pernikahan dini pada masyarakat Sasak Lombok. Jurnal Qawwãm, 13(1), 1-13. Doi: https://doi.org/10.20414/qawwam.v13i1.1619

Landung, J., Thaha, R., \& Abdullah, Z,. (2009). Studi kasus biasaan pernikahan usia dini pada masyarakat Kecamatan Sanggalangi Kabupaten Tana Toraja. Jurnal MKMI, 5(4), 89-94.

Lorenz, F. O., Conger, R. D., Simon, R. L., Whitbeck, L. B., \& Elder Jr, G. H. (1991). Economic pressure and marital quality: An illustration of the method variance problem in the causal modeling of family processes. Journal of Marriage and the Family, 375-388. Doi: http://dx.doi.org/10.2307/352906

Marijo, M. O. D. S. F. (2019). Pribadi orang Sasak dalam teater tradisional Kemidi Rudat Lombok. Jurnal Elementary: Kajian Teori dan Hasil Penelitian Pendidikan Sekolah Dasar, 2(2), 3438. Doi: https://doi.org/10.31764/elementary.v2i2.1298

Muntamah, A. L., Latifiani, D., \& Arifin, R. (2019). Pernikahan dini di Indonesia: Faktor dan peran pemerintah (Perspektif penegakan dan perlindungan hukum bagi anak). Widya Yuridika: Jurnal Hukum, 2(1), 1-12. Doi: https://doi.org/10.31328/wy.v2i1.823

Murahim, N. F. N. (2011). Nilai-nilai budaya Sasak Kemidi Rudat Lombok: Perspektif hermeneutika. Jurnal Mabasan, 5(2), 59-79. Doi: https://doi.org/10.26499/mab.v5i2.211

Pratiwi, B. A., Angraini, W., Padila, P., Nopiawati, N., \& Yandrizal, Y. (2019). Analisis pernikahan usia dini di Kabupaten Bengkulu Tengah tahun 2017. Jurnal Kesmas Asclepius, 1(1), 14-24. Doi: https://doi.org/10.31539/jka.vli1.575

Presiden Republik Indonesia. (1945). Undang-Undang Dasar Negara Republik Indonesia Tahun 1945.

Presiden Republik Indonesia. (1975). Peraturan Pemerintah Republik Indonesia Nomor 9 Tahun 1975 tentang Pelaksanaan Undang-Undang Nomor 1 Tahun 1974 tentang Perkawinan.

Presiden Republik Indonesia. (2003). Undang-Undang Republik Indonesia Nomor 20 Tahun 2003 tentang Sistem Pendidikan Nasional.

Presiden Republik Indonesia. (2004). Undang-Undang Republik Indonesia Nomor 23 Tahun 2004 tentang Penghapusan Kekerasan Dalam Rumah Tangga.

Presiden Republik Indonesia. (2014). Undang-Undang Republik Indonesia Nomor 35 Tahun 2014 tentang Perubahan Atas Undang-Undang Nomor 23 Tahun 2002 tentang Perlindungan Anak.

Rato, D. (2011). Hukum perkawinan dan waris adat (Sistem kekerabatan, bentuk perkawinan dan pola pewarisan adat di Indonesia). Surabaya: Laksbang Yustitia.

Salmah, S. (2017). Pernikahan dini ditinjau dari sudut pandang sosial dan pendidikan. Al-Hiwar: Jurnal Ilmu dan Teknik Dakwah, 4(6), 35-39. Doi: http://dx.doi.org/10.18592/alhiwar.v4i6.1215

Sastra, M. Okta Dwi \& Marijo, F.M. (2019). Pribadi Orang Sasak dalam Teater Tradisional Kemidi Rudat Lombak. Jurnal Elementary, 2, (2), 34-38.

Soekanto, S. (1983). Teori sosiologi tentang perubahan sosial. Surabaya: Ghalia Indonesia.

Solikatun, S., Karyadi, L. W., \& Wijayanti, I. (2019). Eksistensi seni pertunjukan Peresean pada masyarakat Sasak Lombok. SANGKéP: Jurnal Kajian Sosial Keagamaan, 2(1), 1-12. Doi: https://doi.org/10.20414/sangkep.v2i1.349

Sulkhad, K. (2013). Merarik pada masyarakat Sasak. Yogyakarta: Ombak.

Syaifuddin, M., Turatmiyah, S., \& Yahanan, A. (2013). Hukum perceraian. Jakarta: Sinar Grafika. 
64 - Harmoni Sosial: Jurnal Pendidikan IPS

Yin, R.K. (2015). Studi kasus: Desain \& metode. Jakarta : Raja Grafindo Persada.

Zulhadi, H., \& Mohsi, M. (2019). Pandangan Hukum Islam terhadap adat perkawinan endogami masyarakat Sade. Ulumuna: Jurnal Studi Keislaman, 5(1), 78-92. Doi: https://doi.org/10.36420/ju.v5i1.3637 